\title{
SIGNIFICADO ATRIBUÍDO AO SANGUE PELOS DOADORES E RECEPTORES ${ }^{1}$ \\ MEANING ATTRIBUTED TO THE BLOOD FOR DONORS AND RECEIVERS OF BLOOD UN SIGNIFICADO ATRIBUIDO A LA SANGRE SEGÚN LOS DONADORES Y LOS RECEPTORES
}

\author{
Salete Regina Daronco Benetti2, Maria Helena Lenardt ${ }^{3}$
}

\begin{abstract}
${ }^{1}$ Artigo extraído da Dissertação de Mestrado em Enfermagem do Curso de Pós-Graduação em Enfermagem da Universidade Federal do Paraná (UFPR): "Vida e medo: significado atribuído ao sangue pelos doadores e receptores".

${ }^{2}$ Mestre em Enfermagem pela Universidade Federal do Paraná (UFPR). Docente da Universidade do Contestado (UnC), Campus Canoinhas/SC. Membro do Grupo Multiprofissional de Pesquisa sobre Idosos (GMPI).

${ }^{3}$ Doutora em Filosofia pela Universidade Federal de Santa Catarina (UFSC). Docente da UFPR. Líder do GMPI.
\end{abstract}

PALAVRAS-CHAVE: Sangue. Cultura. Enfermagem.

KEYWORDS: Blood. Cultura. Nursing.

PALABRAS CLAVE: Sangre. Cultura. Enfermería.
RESUMO: Trata-se de um estudo etnográfico focado, que teve como objetivo interpretar o sistema de conhecimento e de significado atribuídos ao sangue referente à transfusão sangüínea, pelos doadores e receptores de um banco de sangue. Para a coleta de informações, efetivou-se a observação participante e a entrevista etnográfica. Realizaram-se análises de domínio, taxonômicas e temáticas. Os domínios culturais foram: sangue é vida, fonte de vida e alimento precioso; crenças religiosas: fontes simbólicas de apoio; doação de sangue: gesto prestativo que exige cuidar-se, gratifica e traz felicidade; doação sangüínea: fonte simbólica de insegurança; estar doente é condição para realizar transfusão sangüínea; transfusão sangüínea: esperança de vida; crenças populares: transfusão sangüínea como risco para a saúde; doadores de sangue: pessoas abençoadas; e doar e receber sangue: como significado de felicidade. Emergiu o tema: "líquido precioso que dá origem, sustenta, modifica a vida, provoca medo e insegurança”.

ABSTRACT: This is a focused ethnographic study that had as purpose to interpret the meaning and the system of knowledge attributed to the blood, regarding the blood transfusion, for the blood donors and receivers. For information collection observation and ethnographic interview, domain analisis, taxonomics and thematics were used. Cultural domains were: blood is life, life source and precious food; religious faiths: symbolic sources of support; donation of blood: ready gesture that demands care, rewards and brings happiness; blood transfusion: symbolic sources of insecurity; being sick: condition to accomplish blood transfusion; blood transfusion: life hope; popular faiths: blood transfusion as risk for health; blood donors: blessed people; donating and receiving blood: as meaning of happiness. The thematic: "precious liquid that originates, sustains, modifies life, and provokes fear and instability".

RESUMEN: Se trata de un estudio etnográfico, que tuvo lo objetivo de interpretar el sistema de conocimiento y del significado atribuidos a la sangre referente a la transfusión sanguínea por los donadores y receptores de un banco de sangre. Para la colecta de las informaciones se observaron los participantes y la entrevista etnográfica se realizó el análisis de dominio, taxonómicos y temáticos. Los dominios culturales fueron: la sangre es vida: fuente de vida y alimento valioso; creencias religiosas: fuentes simbólicas de apoyos; donación sanguínea: un gesto colaborador que exige cuidarse, gratifica y trae felicidad; donación sanguínea: fuente simbólica de inseguridad; estar enfermo es una condición para realizar transfusión sanguínea; transfusión sanguínea: esperanza de vida; Creencias populares: transfusión sanguínea como riesgo para la salud; donadores de sangre: personas benditas; donar y recibir sangre: como significado de felicidad. Temática: "líquido precioso que origina, sostiene, modifica la vida, provoca miedo e inseguridad".
Endereço: Salete Regina Daronco Benetti.

R. Barão do Rio Branco, 1345

89.460-000 - Canoinhas, SC.

E-mail: saleterdb@yahoo.com.br
Artigo original: Pesquisa

Recebido em: 12 de agosto de 2005 Aprovação final: 22 de fevereiro de 2006 


\section{INTRODUÇÃO}

A enfermagem trabalha, no seu cotidiano, com dimensões da pessoa, tais como simbolismos, significados, crenças, valores, aspirações e objetivos, porém, a compreensão que tem dos outros e de si mesma é, de modo geral, inconsciente e intuitiva, pois poucas vezes ocorre de maneira sistemática. A busca de referenciais que subsidiem a prática de enfermagem, fundamentada em conceitos e alicerçada nas exigências das pessoas, é imprescindível para que se respeite o seu sistema de conhecimentos e de significados.

Como profissional responsável pelo serviço de hemoterapia, o enfermeiro presta assistência, orienta e supervisiona o doador de sangue, durante o processo hemoterápico nas possíveis intercorrências, elabora a prescrição de enfermagem necessária nas etapas do processo hemoterápico, avalia e realiza a evolução do doador e do receptor junto à equipe multiprofissional, executa e/ou supervisiona a administração e monitoração da infusão de hemocomponentes e hemoderivados, detecta as eventuais reações adversas, registra informações e dados estatísticos pertinentes ao doador e receptor, participa de programas de captação de doadores, desenvolve e participa de pesquisas relacionadas à hemoterapia e à hematologia.

Para alcançar significativa qualidade nas ações que desenvolve, o enfermeiro precisa entender o que a pessoa está expressando, compreender o sistema de conhecimentos e significados a partir da visão dos sujeitos. Isto exige aproximação, investigação, observação atenta, abstenção de julgamentos prévios, tentando alcançar a visão da pessoa, a perspectiva êmica. Conhecer a complexidade de fenômenos culturais, os símbolos e suas relações, dentro de um complexo sistema de significados, no meu entendimento, é condição indispensável para compreender os sistemas de conhecimento e o comportamento das pessoas.

O ser humano age em relação às coisas na base dos significados que elas representam para eles. Estas coisas, "incluem todos os objetos físicos, outros seres humanos, instituições, idéias valorizadas", 1:35 e são colocadas como "símbolos significantes". 2:33 "Os símbolos significantes palavras, gestos, desenhos, sons musicais, artifícios mecânicos ou objetos, já se encontram em uso na comunidade quando o indivíduo nasce e permanecem após a sua morte com algumas alterações, acréscimos, subtrações e alterações parciais dos quais pode ou não participar" 2:33 Isso quer dizer que o ser humano traz consigo muita influência da sua realidade sociocultural. "No âmago de nossa existência, cada um de nós incorpora um mundo de significados únicos dentro de um contexto de significados socialmente aceitos". $3-23$

Tendo em vista o exposto, para este trabalho, foi delineado o objetivo de interpretar os sistemas de conhecimento e de significado atribuídos ao sangue, referente à transfusão sangüínea, pelos doadores e receptores de um banco de sangue.

\section{METODOLOGIA DO ESTUDO}

Para desenvolver este trabalho, optou-se por utilizar a abordagem etnográfica. ${ }^{4-5} \mathrm{O}$ estudo foi realizado no banco de sangue de um hospital localizado na região do Contestado, Planalto Norte Catarinense, distante $380 \mathrm{~km}$ de Florianópolis.

Os atores foram as pessoas que fazem parte do cenário do estudo (funcionários do banco de sangue, doadores e receptores de sangue) e que participaram da pesquisa, de alguma forma, por meio da observação participante ou de respostas aos questionamentos etnográficos. Alguns desses participaram com maior intensidade, como os doze doadores e os oito receptores de sangue, que foram os informantes-chave do estudo. Estabeleceu-se alguns critérios para a seleção dos informantes-chave, assim como: ter condições de manter diálogo efetivo, disponibilidade de tempo para manter o diálogo, desejo de participar da pesquisa.

\section{Coleta de informações}

As informações foram coletadas por meio da observação participante e da entrevista etnográfica. O primeiro contato com os atores do cenário do estudo foi por meio do serviço de hemoterapia do hospital. Inicialmente, realizou-se uma pré-observação, dedicada a alicerçar previamente a observação participante e depois observações gerais por meio de visitas pelo cenário do estudo, com o objetivo de descrever as principais características.

A partir da observação participante, selecionouse os informantes-chave para realizar as entrevistas etnográficas, conforme os critérios estabelecidos anteriormente. $\mathrm{Na}$ entrevista etnográfica, com os informantes-chave, utilizou-se questões descritivas, estruturais e contrastes. As questões descritivas permitiram expandir as informações dos participantes, as quais utilizou-se nas diferentes fases do estudo (coleta de informações, registro e análise). Realizadas as questões descritivas, passou-se para as questões estruturais, com o objetivo de compreender o que as pessoas sabem sobre o sangue e as transfusões sangüíneas e como elas 
organizam o que sabem. Essas questões ajudaram a ampliar os dados descritivos e permitiram o conhecimento da organização sistemática da cultura estudada.

Com as questões contrastes, procurou-se perceber as diferenças na forma como os informantes descreviam os significados do sangue e das transfusões sangüíneas. Estas questões auxiliaram na pesquisa, a comparar como os significados diferem uns dos outros e a entender que os símbolos e significados se relacionam entre si.

\section{Registro das informações}

Desde a entrada no campo, e durante todos os momentos em que estive presente no cenário do estudo, procurou-se registrar as observações e impressões. Realizou-se observação focalizada ao cenário e aos informantes do estudo. Dedicou-se atenção especial a todos os eventos que ocorriam durante a trajetória com o propósito de interpretar o que se passava com os doadores e receptores de sangue.

Os registros etnográficos das observações foram realizados em um bloco de anotações. Registrouse as sentenças relacionadas a eventos experienciados através da observação participante, tomando cuidado para que contivessem o mínimo de interpretação possível. Primeiramente, foram registrados dados característicos do cenário, a planta física, os materiais permanentes e de consumo, a rotina do serviço, os recursos humanos e um breve histórico do banco de sangue.

Para o registro das entrevistas etnográficas, utilizou-se o gravador, com a devida autorização do informante. O registro por escrito das falas gravadas, foi realizado ao término de cada entrevista, assim como as notas que foram escritas no bloco de anotações, e foram transcritas em arquivo próprio, no computador, com o mesmo estilo de linguagem expressada pelos informantes, utilizando nomes fictícios.

\section{Análise das informações}

As informações foram analisadas concomitante à coleta de informações, de acordo com o método etnográfico, ${ }^{5}$ o qual refere que a análise das informações se faz desde o momento em que se começa a coleta. Inicialmente, realizou-se a leitura cuidadosa das descrições, que foram elaboradas a partir das observações, das gravações e dos registros no bloco de anotações, à procura de domínios culturais (categorias de significados), os quais sublinhava e relacionava às relações semânticas correspondentes.
Após análise de domínios, foi feita a análise taxonômica que é um conjunto de categorias organizadas sobre a base de uma só relação semântica, que demonstra as relações de todos os termos incluídos no domínio. A análise taxonômica indica a forma como os subconjuntos estão relacionados como um todo, mostrando os diferentes níveis que existem dentro de cada um.

A partir das análises, estabeleceu-se as relações entre os domínios com o objetivo de formar um conjunto que representasse o pensamento dos informantes acerca do conhecimento e dos significados pertinentes ao sangue e às transfusões sangüíneas, ou seja, foi estabelecido o tema que é uma grande unidade de pensamento, que consiste em um número de símbolos interligados dentro de relações de significados. O tema que emergiu foi: "líquido precioso que dá origem, sustenta, modifica a vida, provoca medo e insegurança”.

\section{Aspectos éticos}

Para o desenvolvimento da pesquisa, encaminhouse o projeto ao Comitê Setorial de Ética em Pesquisa do Setor de Ciências da Saúde da Universidade Federal do Paraná, o qual foi aprovado em reunião do 28 de abril de 2004, sob o registro CEP/SD: 049. SE 013/04-03.

Os critérios de respeito à dignidade do ser humano, à proteção, aos direitos, ao sigilo e ao anonimato foram assegurados pelo Termo de Consentimento Livre e Esclarecido, fundamentado na Resolução 196/ 96, ${ }^{6}$ sobre pesquisa envolvendo seres humanos.

\section{RESULTADOS}

A seguir, os resultados das análises das entrevistas etnográficas, ${ }^{5-7}$ os domínios e o tema que emergiu dessas análises.

\section{Domínio cultural 1 - sangue é vida, fonte de vida e alimento precioso}

A vinculação da vida ao sangue foi feita muito antes de William Harvey (médico nascido em 1578, em Folkestone) ter descoberto a circulação sangüínea, em 1628, assim, em toda a humanidade, este significado foi incorporado culturalmente ao longo dos anos, o que pode ser constatado nos seguintes fragmentos das entrevistas etnográficas: sangue é vida. É vida porque leva alimento pro nosso corpo. O sangue dá origem e mantém a vida (Valmir, abril/2004). É fonte da nossa vida, desde a concepşão no útero. É fonte da vida por que sem ele a gente não vive. A origem da vida desde lá do útero, então já começa daí (Arlei, abril/2004). 
A função de manutenção da vida foi atribuída, pelos informantes, ao sangue que circula no organismo humano, enquanto que à sua ausência é conferido o significado de morte: o sangue é a vida da pessoa, se uma pessoa perde muito ele vai morrendo, se tá doente e não faz. transfusão também morre, o sangue é a vida da pessoa (Pedro, maio/2004).

Ao interpretar o sangue como fonte de vida, os informantes incorporam o cuidado com sua saúde, com seu corpo, como condição para realizarem as doações sangüíneas: eu me cuido pra sempre poder doar, eu tenho saúde e me cuido pro meu corpo fica sempre bem, com saúde (Benedito, junbo/2004).

A referência ao sangue, pelos informantes, como força vital, alimento, combustível, líquido precioso, que atua como uma terapia para reabilitar e ter qualidade de vida, também é encontrada nas literaturas, as quais citam que os povos primitivos untavam-se, banhavamse, bebiam o sangue de jovens e bravos guerreiros para se beneficiarem de suas qualidades, os gladiadores romanos ingeriam sangue para ficarem mais fortes e corajosos, e os gregos reconheciam o sangue como sustentáculo da vida. Tais referências encontram amparo, também, na seguinte afirmação: “[...] para evitar os efeitos da deterioração da sociedade é preciso uma nova energia, recarregar o universo e com ele a sociedade: A máquina do mundo deve ser alimentada de energia vital, de 'água preciosa', quer dizer, de sangue humano". 8:25 Ao tratarem o sangue como algo especial, os informantes demonstram que dependem dele para viver e que, por meio do sangue, um corpo pode ser nutrido ou restaurado.

\section{Domínio cultural 2 - crenças religiosas: fon- tes simbólicas de apoio}

As religiões conferem às pessoas, e em especial aos doadores e receptores de sangue, um sentido de vínculo entre o profano e o sagrado, além do sentimento da diferença entre natural e sobrenatural, há o sentimento da separação entre o humano e o divino: $o$ sangue de Cristo é diferente, Ele derramou para salvar a bumanidade. É diferente do sangue doado, porque Ele derramon o sangue por nós no calvário né, deu a vida [...] Por isso acho que o sangue é vida, tanto a vida terrena quanto a vida de Cristo, a espiritual, a vida eterna (Pedro, maio/2004). Os informantes interpretam o sangue de Cristo como a vida espiritual, o sangue da vida eterna.

Das literaturas que fazem referência ao sangue como vida espiritual ou com conotação religiosa, des- taco a seguinte: "o sangue não é somente o agente da vida, é também o da salvação: o sangue do redentor, do mártir, do herói; hoje, sangue desconhecido que leva a vida para situações críticas onde o indivíduo está em perigo de morte". 8:203

\section{Domínio cultural 3 - doação de sangue: gesto prestativo que exige cuidar-se, gratifica e traz felicidade}

O ser humano é ser de possibilidades, com aspirações, com desejos e vontades e com certo grau de liberdade, de poder e escolha. A liberdade da escolha de ser doador implica preocupar-se com a manutenção da saúde e com a busca da felicidade, como mostram os relatos de alguns dos informantes doadores: [...] eu me cuido pra sempre poder doar, en tenho saúde e me cuido (Benedito, junbo/2004). [...] eu tenho saúde, me valorizo, amigos meus já morreram de AIDS porque não se cuidaram. Eu me cuido pra poder doar (Antony, maio/2004). [...] en me sinto feliz, porque en ajudei a salvar uma vida (Merci, maio/2004). Fico gratificado porque meu sangue salva vidas e en tenho saúde (Antony, maio/2004).

Nas entrevistas etnográficas identifiquei que, para os informantes, ter saúde é condição para ser doador. "A saúde é um processo muito particular de percepção individual e do entendimento que cada ser humano tem em relação às suas necessidades e vontades, comparados à demanda que possui para manterse e sobreviver no ambiente de suas relações" 9:37

Embora alguns informantes tenham feito referência ao cuidado que têm em manter uma "saúde boa", em algumas entrevistas etnográficas, interpretei que a preocupação em ajudar o outro, em salvar a vida de outras pessoas se sobrepõe aos cuidados com a sua própria vida: a primeira vez que doei sangue foi para socorrer um acidentado, primeiro tiraram meu sangue e passaram, depois pediram de novo. Doei duas vezes no mesmo dia (Antony, maio/2004). Interpretei que este doador descreve que, ao alguém estar em perigo de vida, o ser humano se esforça para ajudar, mesmo sob risco pessoal.

A doação de sangue é enfatizada como um gesto social que pode ocorrer entre familiares ou entre pessoas desconhecidas. "[...] aquele que doa parece estar não só procurando manter e melhorar a vida de seu parente, mas também manter algo de sua identidade enquanto pessoa membro daquela família". ${ }^{10: 172} \mathrm{Meu}$ filho ficon doente precison sangue, doei para ele. Agora ele tem mais um pouco do men sangue (Franco, maio/2004). 


\section{Domínio cultural 4 - doação sangüínea: fonte simbólica de insegurança}

As significações a respeito do sangue, abordadas na pesquisa, têm peculiaridades e aspectos próprios da identidade cultural e tornam-se mais discrepantes quando comparadas ao conhecimento acadêmico. Os sintomas físicos, relatados por alguns dos informantes, após a doação de sangue, são fontes simbólicas de insegurança em realizar as doações e passíveis de diferentes leituras em busca de significados atribuídos à doação sangüínea. Acho que depois de doar pode dar uma espécie de fraqueza, um mal estar passageiro, uma coisinba assim, é uma coisa que está saindo da gente (Arlei, abril/2004, $1^{a}$ doação). Eu achava que ia dar tontura, cair na rua sozinha, né? Porque tirando sangue a gente pode ficar fraca, dar uma espécie de tontura, fraqueza (Merci, maio/2004).

Os sentimentos de insegurança e incerteza, que emergem das falas dos informantes, são aspectos a serem considerados ao tentar interpretar os significados atribuídos à doação sangüínea. Estes sentimentos, angústias, dizem respeito à tomada de consciência da sua situação de doador de sangue, de sua desproteção e desamparo por não saber exatamente o que irá acontecer após a finalização do processo. São uma realidade que todo ser humano vivencia, que faz parte do homem durante toda a sua existência e são fatores que o auxiliam a enfrentar o cotidiano e a tomar consciência do sofrimento de estar lançado no mundo.

\section{Domínio cultural 5 - estar doente é condição para realizar transfusão sangüínea}

A necessidade de realizarem transfusão sangüínea é caracterizada pela presença da doença. A doença se apresenta quando o ser humano tem limitações, dificuldades, falta de condições para suprir as demandas necessárias para trabalhar, viver melhor, sobreviver e os informantes sentem-se limitados nas suas capacidades de trabalho: comecei trabalhar e sentia muito sono, cansaço, fui consultar e o médico falou que tenho anemia profunda, dai me mandaram tomar sangue (Luciane, junbo/2004). Tenho muito problema de saúde [...], tenho problema nos olhos e agora com a diabete ficou pior. Tomei sangue pra continuar vivendo, pra cuidá da minha filha (Iracema, junho/2004).

A tristeza, presente nos discursos dos informantes receptores de sangue, sintetiza a trajetória de vida, e está envolvida em complexa rede de sentimentos que representam vários aspectos da vida da informante. Estes sentimentos orientam os informantes em suas buscas pelos significados e ajudam a explicar porque determinada doença aconteceu em dado momento: $e u$ sô evangélico, não sô fanático, mas eu recebi uma bênção e já tava curado, então cometi uma desobediência e voltei a ficar doente (Cleiton, junho/ 2004).

A doença representa a experiência da fragmentação e do estranhamento da pessoa para consigo mesma. A doença justifica a realização da transfusão sangüínea: eu tenho anemia e não sarei com as injeções de vitamina que tomei, ai o médico falou que eu tinha que tomar sangue pra me curar (Lúcia, junbo/2004). [...] en tava muito debilitada, sofrendo muito, precisava prolongar minha vida, ter uma vida melhor. Eu precisei de sangue (Ane, junho/2004).

A compreensão do fenômeno saúde/doença está associada aos significados culturais de cada ser humano, que pode ser modificada ou adaptada conforme o meio em que está inserido. Os informantes expressam preocupação com a manutenção da saúde, com a percepção de si mesmos e com a imagem que passam para os outros, e preocupam-se em retornar às suas atividades diárias e melhorar a qualidade de vida. Os informantes, doadores de sangue, buscam, constantemente, preservar a sua saúde para cuidar da saúde de outros.

\section{Domínio cultural 6 - transfusão sangüínea: es- perança de vida}

Para alguns informantes receptores, o sangue representa a vida e a transfusão sangüínea é considerada um benefício que não altera suas vidas ou sua maneira de ser, porém restitui as condições para terem uma vida melhor, devolve-lhes um sentimento nato do ser humano, a esperança: muita gente morre por falta de sangue. Se ele salva a vida de uma pessoa ele também cura quem tá doente, eu tenho esperança de continuar vivendo (Luciane, junbo/2004).

A esperança desempenha um papel fundamental na vida do ser humano no mundo, e a considero essencial para o enfrentamento das doenças. Os informantes do estudo compartilham esse sentimento, pois enquanto uns doam na 'esperança' de salvar vidas, os outros, enquanto receptores de sangue, depositam suas esperanças de cura no tratamento e, ao compartilharem este significado, doador e receptor, passam a valorizar mais a sua própria existência.

A alteração no cotidiano das pessoas doentes, nas relações familiares, sociais ou de trabalho, interfere e transforma o ser humano, bem como a sua história existencial. Nesta transformação, o tratamento, por meio da transfusão sangüínea, para alguns informantes receptores, tem o significado de purificação: [...] 
acho que o sangue na transfusão é para purificar ou para repor o que a gente perde. Purificar significa tirar o que tem de ruim no corpo, porque o sangue da transfusão é limpo, se a gente tem alguma doença e recebe sangue limpo, ele purifica, é como a água que a gente toma (Vitório, junbo/2004).

\section{Domínio cultural 7 - crenças populares: trans- fusão sangüínea como risco para a saúde}

Em algumas das significações, atribuídas pelos informantes, foi possível interpretar o sangue da transfusão como veículo para transmissão de doenças, portanto, considerado sangue impuro. "O sangue impuro não veicula mais a vida, mas a morte. Pode matar os que o recebem. O risco leva alguns a se protegerem do recurso eventual de um sangue anônimo - suspeito, talvez maldito - prevendo um dom recíproco com os doadores conhecidos, os próximos, ou fazendo da conservação de seu próprio sangue o primeiro (e necessário) seguro de vida". 8:204

Ter que realizar transfusão sangüínea, para alguns dos informantes receptores, é motivo de angústia, medo, insegurança. As incertezas referentes aos resultados da transfusão, o desconhecimento que os receptores de sangue têm em relação às pessoas que atuam na instituição e aos testes realizados no sangue geram o medo e o nervosismo: [...] no momento, eu não aceitei, achei ruim, fiquei meio com medo de tomar este sangue [...] Eu tava com medo porque quantos riscos que pode correr com o sangue, riscos de pegar doença, sei lá, tenho medo da Aids, hepatite (Prima, maio/2004).

\section{Domínio cultural 8 - doadores de sangue: pes- soas abençoadas}

Pela benevolência dos gestos, os informantes do estudo atribuem aos doadores de sangue o significado de "anjos"; estabelecendo, desta forma, um sentido religioso de criaturas sagradas ou, na linguagem cultural, abençoadas. Os anjos são considerados, por muitas pessoas, criaturas celestes e espirituais. Esta, talvez, seja a definição que mais se aproxima do significado que têm, para os informantes doadores de sangue, uma vez que, se os "anjos" são criaturas celestes, estes podem assumir formas reais, como seres doadores, que vêm para socorrer os homens, confortar e acompanhá-los sempre: os doadores são os anjos de Deus, são seres anjos que vão lá e te dão sangue sabendo que vão fazer o bem, é lindo, só quem precisa é que sabe (Ane, junbo/2004).

A expectativa, a sensação de estar curado graças à benevolência de alguém reforça a necessidade de agradecer a vida recebida por meio dessa pessoa, com isso, o doador de sangue é engrandecido na hierarquia simbólica do receptor, pela nobreza e grandeza do seu gesto: [...] estas pessoas são abençoadas, merecem uma vida feliz. (Ane, junbo/2004).

\section{Domínio cultural 9 - doar e receber sangue como significado de felicidade}

Por meio da significação simbólica as pessoas idealizam e realizam sua história cultural. Esta história pode trazer satisfação e felicidade, de acordo com o que cada um deseja. Os receptores de sangue sentemse felizes por serem beneficiados pelo ato solidário de alguém, enquanto que a felicidade, relatada pelos doadores de sangue, pode estar associada ao prazer em ajudar o outro.

A necessidade de doar sangue pode estar relacionada à busca constante de satisfação, pois a doação sangüínea tem caráter perene, ou seja, marca o corpo com a experiência vivida. Sangue pra mim é uma vida feliz, uma vida com qualidade, sangue é isso, é o essencial pra você ter qualidade de vida e ter felicidade (Ane, junho/2004).

As falas dos informantes traduzem o desejo de serem felizes, pois estabelecem valores que esperam culminem com suas expectativas de realização plena. A partir dos significados que os informantes atribuem às doações e às transfusões sangüíneas, caracterizados, neste domínio, como felicidade, constroem os seus sonhos e organizam suas vidas.

\section{TEMA: LÍQUIDO PRECIOSO QUE DÁ ORIGEM, SUSTENTA, MODIFICA A VIDA, PROVOCA MEDO E INSEGURANÇA}

Muitas interpretações sobre o sangue foram identificadas através dos relatos dos informantes. Foi evidenciado que para o receptor, ao mesmo tempo em que restitui a vida, o sangue provoca medo, e para o doador a possibilidade de que algo lhe aconteça após a doação sangüínea traz insegurança. A dualidade de significados em relação à transfusão sangüínea, ser ruim e ser necessário, representa os conflitos internos a que o receptor de sangue está sujeito, porém nos discursos dos informantes prevaleceu o significado de vida.

Alguns relataram casos em que lhe atribuem o significado de líquido precioso que dá origem e sustenta a vida. Fazendo uma comparação com a água, que é essencial à vida e o líquido mais importante que a terra fornece à humanidade, e o sangue, sendo líquido, passa a ter a mesma importância para os informantes, então, atribui-se a ele o significado de líquido 
precioso, o que confere com a seguinte referência: “o sangue permanece o líquido 'precioso' que circula, irriga o organismo, mantém a vida e a protege das agressões patogênicas [...]". 8:203

O sangue da transfusão, para alguns informantes, possui um significado de salvação de vidas, para outros a transfusão foi expressa como uma possibilidade de mudança (metamorfose). Busquei estabelecer um paralelo entre a metamorfose humana e a dos insetos: "a metamorfose da lagarta em borboleta oferece uma metáfora interessante: quando a lagarta entra no casulo, ela opera a autodestruição de seu organismo de lagarta, e esse processo é, ao mesmo tempo, de formação do organismo da borboleta, que será, ao mesmo tempo, a mesma que a lagarta", ${ }^{11: 3}$ isto significa dizer que, ao deparar-se com situações que não pode resolver por si só, o homem é capaz de buscar soluções para os seus problemas, de "metamorfosear-se".

A metamorfose pode ocorrer internamente, conforme pude interpretar pelas falas dos informantes doadores de sangue, quando expressaram que, após as doações, sentem uma sensação de bem-estar. Porém, a metamorfose pode ocorrer, também, externamente, pelo reconhecimento da sociedade, pois à medida que realizam a doação sangüínea tornam-se pessoas diferenciadas, cumprem seu papel social de seres solidários, participativos, e isso os enaltece perante o receptor e a comunidade em que vivem. Os receptores, por sua vez, igualmente descrevem a transformação que ocorre em suas vidas, quando vêem a saúde restabelecida de pessoas fragilizadas pela doença, muitas vezes sem esperança, passam a seres com energia renovada, adquirindo uma nova perspectiva de vida.

Alguns doadores de sangue expressaram histórias de vida, trajetórias pessoais ligadas a doenças, a sofrimento, por isso, atribuem à transfusão sangüínea um significado que ultrapassa os limites da experiência da doença física e determina a construção de uma nova identidade sociocultural. "O homem não vive num universo puramente físico, mas num universo simbólico, [...] são vários os fios que tecem a rede simbólica, a teia emaranhada da experiência humana". 12:48

Para a maioria dos informantes, a doação de sangue está ligada a fatores emocionais e é enfatizada como um gesto social que pode ocorrer entre familiares ou entre pessoas desconhecidas. No contexto estudado, interpretei a solidariedade como sinal de sensibilidade com a dor e o sofrimento alheios, um processo de construção gradual, que fortalece a convivência e as relações sociais, que compreende a reciprocidade e a disponibilidade, bases de sustentação das relações de aju- da, de satisfação das necessidades e anseios do ser humano na sociedade.

As pessoas percebem o que está ao seu alcance para mudar. Alguns informantes doadores, após a decisão de doar sangue, relataram que adotaram uma atitude mais positiva em relação à vida, procuraram mudar hábitos para terem uma qualidade de vida melhor e manterem a saúde. Outros informantes, receptores de sangue, após as transfusões sangüíneas, passaram a ter esperança de que haveria mudança em suas vidas. A condição de ter sido ou estar curado, graças à transfusão de sangue, representa a compensação pelo sofrimento por que passaram alguns dos informantes receptores de sangue.

\section{CONSIDERAÇÕES FINAIS}

Os símbolos são criados pelos homens, compartilhados entre eles, usados para comunicarem-se e recebem um determinado significado em razão do contexto cultural em que vivem. Os informantes do estudo utilizam símbolos para elaboração dos significados a respeito do sangue e das transfusões sangüíneas. Os símbolos foram elaborados a partir de suas vivências individuais, sustentados pela convivência social e inseridos no contexto cultural. "Neste sentido, a cultura constitui-se no vivido cotidianamente, significando ação humana, simbolismo". 13:178

As interpretações são complexas, por isso não são fáceis de serem realizadas. Como observadora participante, por mais que tentasse ver as coisas do ponto de vista emic, não fui capaz de perceber aquilo que os informantes percebem, ou a maneira como o percebem, e o que pude interpretar foi a expressão oral e a maneira como eles sinalizavam com gestos e movimentos faciais.

Foi necessário compreender o que os informantes sabem, por que agem e pensam de determinado modo, e os significados que são capazes de atribuir ao sangue referente às transfusões sangüíneas, de conservar ou de transformar o que sabem. Foi um processo que exigiu observação atenta, sensibilidade, respeito pelas idéias das pessoas e inserção no cenário cultural, para poder interpretá-los.

O cenário do banco de sangue é um todo complexo, e as identidades que ali estão incluem saberes, crenças, costumes e valores que levam o ser humano à mobilização pela solidariedade e à criação de uma identidade coletiva, na busca da valorização pela vida. "Através de uma vida solidária pode-se ter ganhos reais, e o crescimento como ser humano será significativo, tor- 
nando possível alcançar-se uma vida plena e saudável". 9:30

Interpretar os significados e, em especial, o simbolismo do sangue relacionado à transfusão sangüínea favorece a compreensão a partir da visão dos sujeitos, podendo contribuir para uma maior aproximação entre profissionais da saúde e doadores e receptores de sangue e, por meio da atuação profissional, para a redução ou a minimização dos conflitos religiosos, culturais e sociais, respeitando o ser humano e atuando na promoção, proteção e recuperação da saúde.

Da presente pesquisa, surge o convite a continuar no caminho do descobrimento cultural, tendo em vista a perspectiva êmica dos doadores e receptores de sangue, pois as significações interpretadas são específicas do universo cultural dos informantes do estudo e nem sempre podem estender-se a outros cenários culturais, uma vez que não se caracterizaram como construções universais, porém, podem ser geradores de questões para outros estudos.

\section{REFERÊNCIAS}

1 Haguette TMF. Metodologias qualitativas na sociologia. Petrópolis, RJ: Vozes; 2001

2 Geertz C. A interpretação das culturas. Rio de Janeiro: LTC; 1989.

3 Hycner R. De pessoa a pessoa: psicoterapia dialógica. São Paulo: Summus; 1995.

4 Spradley JP, McCurdy DW. The cultural experience: ethnography in complex society. Chicago: SRA; 1972.
5 Spradley JP. Participant observation. Orlando: Library of Congress; 1980.

6 Conselho Nacional de Saúde (BR), Conselho Nacional de Saúde. Comitê Nacional de Ética em Pesquisa com Seres Humanas. Resolução No 196 de 10 de outubro de 1996: diretrizes e normas regulamentadoras da pesquisa envolvendo seres humanos [citado 2003 Jul 22]. Disponível em: http://www.ufrgs.br/hepa/gppg/ res19696.htm

7 Spradley JP. The ethnographic interview. New York: Holt, Rinehart and Winston; 1979.

8 Balandier G. A desordem: elogio do movimento. Rio de Janeiro: Bertrand Brasil; 1997.

9 Bettinelli LA. Cuidado solidário. Passo Fundo: Bertier; 1998.

10 Borges ZN. Motivações para doar e receber: estudo sobre transplante renal entre vivos. In: Duarte LFD, Leal OF. Doenças, sofrimento, perturbação: perspectivas etnográficas. 2a ed. Rio de Janeiro: Fiocruz; 2001. p.169-79.

11 Morin E. Rumo ao abismo inevitável. Especial para o jornal Lê Monde. [citado 2004 Out 10] Disponível em: http:// www.comitepaz.org.br/rumo_ao_abismo.htm.

12 Casirer E. Ensaio sobre o homem. São Paulo: Martins Fontes; 2001.

13 Budó MLD; Saupe R. Modos de cuidar em comunidades rurais: a cultura permeando o cuidador de enfermagem. Texto Contexto Enferm. 2005 Abr-Jun; 14(2):177-85. 